\title{
Editorial
}

\section{O mal-estar da ética no âmbito das migrações}

Seria um erro afirmar que a governança das migrações, na atualidade, não possua algum fundamento ético. As políticas restritivas e securitárias de controle da mobilidade humana, de externalização das fronteiras e de inclusão diferenciada de migrantes são alardeadas em nome de sólidos princípios: a luta contra o terror, a defesa dos direitos humanos, o bem-estar da população, a preservação da identidade cultural da nação, a luta contra o tráfico de pessoas.

No entanto, o que chama a atenção nesta difundida retórica é a negação ou limitação da universalidade desses princípios. Ou, nas palavras de Bauman, "o que é total ou incondicionalmente estranho à qualidade de 'ter moral', e o que milita contra ela, é a tendência de restringir a responsabilidade moral pelos outros e renunciar a ela na fronteira entre 'nós' e 'eles'" (Estranhos à nossa porta, 2017, p. 70). Esse "tribalismo", que contrapõe "nós" e "eles", "cidadãos" e "não-cidadãos", faz com que assuntos que envolvem "os outros" sejam tratados numa ótica meramente técnica ou burocrática e, desta maneira, "a questão se transfere de um plano ético a um plano gerencial, onde não há mais espaço para a moral" (AIME, Marco. Senza sponda, 2015, p. 28). Não há mais tragédias, apenas "efeitos colaterais". Não há mais guerras, apenas "missões de paz". Não há mais sentimentos de culpa, apenas realismo pragmático.

O lugar de nascimento ou umas gotas de sangue - como nos sistemas de castas ou nos privilégios feudais - determinam as fronteiras entre o humano e o sub-humano, entre o ético e o burocrático. Não é de se estranhar, portanto, que argumentos éticos sejam utilizados para legitimar "nossos" hediondos atos de violência - como guerras (preventivas), ataques de drones, embargos comerciais punitivos, omissão de socorro a embarcações à deriva -, mas desconsiderados diante de povos que fogem do terrorismo ou da insegurança alimentar.

Emblema desse mal-estar da ética é o assim chamado "crime de solidariedade" ou "crime humanitário", esta estranha tentação a que estão sujeitos seres humanos que obstinadamente se recusam a comportar-se "como se os outros não fossem - ou, de qualquer modo, não inteiramente - seres humanos" (TODOROV, Tzvetan. O medo dos bárbaros, 2010, p. 27), que não toleram engavetar questões éticas no departamento de assuntos técnicos ou administrativos. 
Visando aprofundar esse mal-estar da ética no âmbito das migrações, o presente número da REMHU, Revista Interdisciplinar da Mobilidade Humana, traz um Dossiê com o tema "Dilemas éticos das migrações".

No primeiro artigo, Paolo Gomarasca aborda o caso da assim chamada "crise migratória" de 2015 na Europa. Ao analisar documentos da União Europeia, o autor evidencia a presença dialética de duas abordagens, uma securitária e a outra humanitária, sendo a segunda incluída (e neutralizada) no interior da primeira - o que dá origem à assim chamada "segurança biopolítica". Uma ética das migrações, segundo Gomarasca, deveria ser construída a partir de uma governança que privilegie a "co-pertença" (appartenenza), a partilha de uma "casa comum", para além de abordagens meramente securitárias ou assistencialistas.

O princípio da justiça distributiva enquanto fundamento da migração é o tema do artigo de Daniel Loewe. O autor apresenta as argumentações de diferentes teorias e, mesmo reconhecendo que a migração não representa o caminho mais efetivo para a justiça distributiva global, afirma que "es díficil descartar la totalidad de estos argumentos a favor de la justicia global. Aunque no estemos de acuerdo con las consecuencias institucionales que el reconocimiento de su fuerza vinculante traería consigo, es poco convincente argumentar que este tipo de obligaciones no existe y que por tanto no deben tener ninguna consecuencia institucional" (p. 38).

Ao tema da hospitalidade em Jacques Derrida é dedicado o artigo de Ana Paula Penchaszadeh. Partindo da experiência de trabalho em um arquivo do filósofo francês, a autora reflete sobre o assim chamado "mal de arquivo" e sua vinculação com as dinâmicas migratórias, as quais questionam a ordem estabelecida, a obsessão por papeis e "la fantasía de unidad que se encuentra a la base de toda comunidad (como-unidad): las migraciones introducen la anarquía democrática". A política e a ética - a poética - são profundamente desafiadas pela irrupção do convidado inesperado, "sin papeles", sendo que a experiência de "acogida incondicional del otro sólo puede tener lugar (y tiene lugar, de hecho, cada vez) como transgresión de la regla y renuncia a todo pedido de papeles" (p. 55).

Lourdes Basualdo debate o espinhoso tema da "inclusión diferencial" de migrantes na sociedade de recepção, a partir do tema da lei de transplantes de órgãos na Argentina. Após analisar as normativas que regulam o acesso dos imigrantes ao tratamento, a autora evidencia como a retórica humanitária da "protección" dos grupos vulneráveis e da criminalização do assim chamado "turismo de transplante" é utilizada a fim de legitimar a exclusão dos migrantes sem residência permanente. Desta forma, essa política pública se torna um filtro de seletividade migratória, que alimenta uma preventiva suspeita em 
relação à população estrangeira "irregular", enquanto ilegítima "consumidora" de órgãos de transplante.

Finalmente, a ética no processo de investigação científica na área das migrações é abordada por Rosalía López Fernández. Partindo da experiência concreta de um trabalho de pesquisa junto a um grupo organizado de mulheres migrantes, a autora desenvolve uma articulada reflexão acerca das implicações éticas relacionadas à atividade de investigação acadêmica, questionando o assim chamado "racismo espistémico" e as limitações - frequentemente encobertas - das categorias analíticas. A autora sugere a necessidade de uma "mayor vigilancia epistemológica" (p. 93) que evite a reificação e a invisibilização dos sujeitos migrantes.

Na seção Artigos, María José Magliano analisa as trajetórias laborais de peruanos na cidade de Córdoba, na Argentina, e sua vinculação com a assim chamada produção do espaço. Conforme a autora, o saber-fazer do trabalho se torna uma ferramenta para a transformação funcional e estética das moradias individuais, bem como do espaço público do Bairro, num contexto caracterizado pela precarização do trabalho e pela presença "economizada" do Estado. O texto levanta o debate sobre vários temas, como o direito à cidade, o protagonismo dos migrantes, a solidariedade comunitária e o papel da sociedade civil em contextos marcados pela relativa ausência do Estado.

A inserção de migrantes paraguaios no mercado de trabalho da área da construção em Buenos Aires é o foco da contribuição de Álvaro Alejandro Del Águila. Mediante dados estatísticos e relatos obtidos em pesquisas de campo, o autor ressalta que uma boa parte dos migrantes paraguaios é oriunda de áreas rurais, com pouca ou nenhuma experiência de trabalho na área da construção. A segmentação do mercado de trabalho, nesta perspectiva, não decorre prioritariamente de experiências ou competências profissionais, e sim de "procesos sociales más profundos e históricamente construidos de discriminación y segregación socio-laboral de los migrantes" (p. 129).

Pablo Sebastián Gómez e David Sanchez Soria, por sua vez, se debruçam sobre a incorporação espacial dos migrantes peruanos na cidade de Córdoba, na Argentina. Numa abordagem sociodemográfica, os autores investigam a segregação espacial dos peruanos em relação com os autóctones e, posteriormente, comparam as características sociodemográficas da população migrante geograficamente agrupada e dispersa, a partir de variáveis como: classe social, gênero e instrução. Os resultados apontam continuidades e descontinuidades em relação ao passado recente.

Gemma Antón Ramos reflete desde uma perspectiva antropológica acerca da sobrequalificação laboral de brasileiras em Barcelona, focando a reflexão principalmente a partir de aspectos socioculturais e subjetivos. 
A sobrequalificação é entendida como um significante que expressa a desvalorização da mulher num processo que utiliza "las distinciones de sexo, etnia y clase para la jerarquización de las actividades laborales" (p. 168); por outro lado, na percepção subjetiva das mulheres pesquisadas, o trabalho adquire significados específicos enquanto necessidade econômica e, sobretudo, recurso de autorrealização. O artigo enfatiza a necessidade de super abordagens epistemológicas meramente economicistas no que diz respeito ao tema do trabalho.

Sebastián Umpierrez De Reguero, Régis Dandoy e Tatiana Palma abordam o tema da participação políticas de emigrantes equatorianos no que diz respeito à assim chamada representatividade especial (isto é, a representação política dos migrantes no país de origem). Mediante uma pesquisa quantitativa, os autores buscam verificar hipóteses acerca da percepção por parte dos equatorianos residentes no exterior sobre a importância de reservar assentos parlamentares para eles. Além de levantarem o debate sobre a relação entre o Estado de origem e os emigrantes, os resultados apresentam elementos desafiadores, sobretudo no que diz respeito à participação em grupos associativos.

No último artigo da revista, Mary Yoko Okamoto, José Sterza Justo e Cizina Célia Fernandes Pereira Resstel refletem sobre os desafios da inserção sócio-cultural de filhos de dekasseguis que regressam ao Brasil. Os/as autores/ as chamam a atenção acerca da sensação de desamparo e estranhamento psicológicos por parte de crianças e adolescentes, principalmente no que diz respeito à inserção no contexto escolar e à comunicação com um novo idioma. Tais desafios, que tendem a aumentar em decorrência do crescente transnacionalismo, se tornam mais complexos pela escassez, senão ausência, de políticas de apoio.

A seção Relatos e reflexões apresenta uma interessante comunicação de Menara Lube Guizardi sobre a recente "crise" migratória no Meditterâneo e a questão da alteridade. Por fim, a resenha de Cynthia Alejandra Pizarro do livro Contemporary Conversations on Immigration in the United States. The View from Prince George's County, Maryland encerra o número da Revista.

Desejamos a todos e todas uma boa leitura!

Roberto Marinucci (editor-chefe da REMHU) 